\title{
Transformation of legal education in modern conditions
}

\author{
Natalia Nikolaevna Bocharova $^{1^{*}}$, Nikolai Viktorovich Veretennikov ${ }^{2}$ \\ ${ }^{1}$ Southern Federal University, Department of Financial Law, Rostov-on-Don, Russia \\ ${ }^{2}$ Southern Federal University, Department of Criminal Procedure and Criminalistics, Rostov-on-Don, \\ Russia
}

\begin{abstract}
The article examines the main trends in education, including legal education. The authors studied the Federal Law "On Education", educational standards, and a number of industry laws; identified the positive and negative sides of digitalization of education, and also separately studied the impact of distance learning in the conditions of coronavirus restrictions as a side of digitalization. It is concluded that the transition to a new paradigm of education corresponds to the constitutional values of Russia. The competency-based approach creates prerequisites for the creative development of a person based on his/her activity and involvement in the learning process. Digitalization in education makes it possible to optimize and improve a number of educational procedures; however, as the authors showed in the study, it also has negative sides in legal education. The distance learning mode as part of digitalization also received a mixed assessment. The authors concluded that universities should carefully comprehend the experience of digitalization and distance learning in the conditions of coronavirus restrictions in order to eliminate problems and improve the educational process.
\end{abstract}

Keywords: education, competencies, educational standards, digitalization, distance learning

\section{Introduction}

The processes of transformation today have affected many spheres of the life of the state and society, including education. It was impossible to build a new statehood in the post-Soviet space without changing the basic paradigm of education, which was developed through the Federal Law "On Education" and educational standards [1]. The implementation of the educational concept is also influenced by digitalization, which was most clearly manifested in the conditions of coronavirus restrictions in 2020-2021. Studies conducted on this topic do not give an unambiguous assessment of these processes: Babinova notes the prerequisites for activating the creative development of the individual; experts of the Higher School of Economics talk about innovative tasks of education; Klochkova introduces the concept of "digital competencies" that should be formed in the

\footnotetext{
* Corresponding author: nbocharova@sfedu.ru
} 
modern educational environment. In the presented article, the authors tried to critically comprehend the impact of the main trends on legal education, highlighting the positive and negative aspects.

\section{Materials and methods}

In the presented article, the hypothesis is formulated that modern education is influenced by several factors. Based on this, the goal was set to study the transformation of education in the current conditions through the example of legal education. To achieve this goal, it is necessary to solve a number of tasks: to study the prerequisites and implementation of the competence approach in legal education; to analyze the main trends of digitalization in education and the impact of the period of "coronavirus" restrictions on this process. The main method of research was the formal-logical one - the study of the Federal Law "On Education", as well as federal state educational standards. The authors also relied on the experience of teaching.

\section{$3 \quad$ Results}

Today, higher education is influenced by three main trends: the competence approach, the introduction of information technologies (digitalization), and coronavirus restrictions. Let us take a closer look at each of these areas.

In accordance with the Federal Law "On Education", participants in educational relations are students, parents (legal representatives) of underage students, teaching staff and their representatives, and organizations engaged in educational activities. The interaction between these participants is based on the principle of subject-subject relations $(\mathrm{S} \rightarrow \mathrm{S})$.

Subject-subject relations $(\mathrm{S} \rightarrow \mathrm{S})$ are a type of relations that develops in the educational process, consisting in creating parity participation of students and teachers in the organization and implementation of joint activities [2]. Subject-subject relations imply the identification of the student as a subject, the recognition of the key value of the entire educational process, the development of a student's abilities based on individual capabilities as the main goal of education [3], in contrast to the Soviet education system built on the subject-object system of relations $(\mathrm{S} \rightarrow \mathrm{O})$, where the teacher is the subject, that is, an active person, and the student is the object of the teacher's influence. In fact, learning in subject-subject relations in education is a purposeful two-way process of transferring and assimilating knowledge, skills, and skills carried out by both the teacher and the student.

In this context, the experience of Finland is interesting, where education is focused on the student. According to the research conducted within the framework of the International Program for the Assessment of Educational Achievements of Students (PISA), Finland has been showing very good results over the past ten years, and Finnish schoolchildren are at the top of international rankings. Finland is one of the rare countries where a high level of student achievement is combined with life satisfaction (PISA 2018). Finnish schoolchildren feel more comfortable and study more effectively compared to other European children [4].

This educational paradigm is primarily focused on the development of the individual, increasing his/her activity and creative abilities. It also correlates with one of the main constitutional values enshrined in the Constitution of the Russian Federation [5] - civil society. In the works of modern researchers, civil society appears as a system of private and 
interpersonal relations of a social, political, ideological, cultural, religious, family, or other nature, directing people's activities to ensure conditions for the comprehensive development of the individual [6]. For this purpose - to activate the creative and psychological potential of a student - the use of methods of students' independent work, self-control, active and interactive teaching methods is increasing.

This trend has been consolidated and developed in educational standards (federal and specific universities). For example, one of the universal competencies of a bachelor in the field of training 40.03.01 Jurisprudence is the ability to manage one's time, build and implement a trajectory of self-development based on the principles of lifelong education [7]. The following universal competency is fixed in the Federal State Educational Institution in the direction of training 40.04.01 Jurisprudence: the ability to determine and implement the priorities of one's own activity and ways to improve it on the basis of self-assessment [8]. At both levels of training (bachelor's and master's degree), these competencies are located in the section "Self-organization and self-development (including health care)", which confirms the conclusion about the orientation of the modern education system, including legal education, to train specialists with a high level of creative potential development, who are able to systematically solve various tasks, and shows the continuity of tasks between levels of training during their development.

Other universal competencies are also aimed at solving the same problem at the Federal State Educational Institution: bachelor's degree - the ability to carry out social interaction and realize one's role in a team (teamwork and leadership); the ability to determine the range of tasks within the set goal and choose the best ways to solve them, based on existing legal norms, available resources and restrictions (project development and implementation) [7]; master's degree - the ability to organize and manage the work of the team, developing a team strategy to achieve the goal (teamwork and leadership); the ability to manage the project at all stages of its life cycle (development and implementation of projects) [8].

Here it is impossible not to mention another interesting trend in education, which is that in accordance with the Federal Law "On Education", as well as within the framework of the concept of the "Bologna" education system, there is no requirement for the coincidence of bachelor's and master's degree courses. On the one hand, there is a plus in this - the student can independently form his/her own trajectory of professional development. On the other hand, there are a number of professions that involve the assimilation of basic knowledge in the bachelor's degree and their consolidation and development at the master's level in one specialty. For example, prosecutors may be citizens of the Russian Federation who have received a higher legal education in the specialty "Jurisprudence", or a higher education in the field of training "Jurisprudence" with the qualification "master" in the presence of a bachelor's degree in the field of training "Jurisprudence", or higher education in the specialties included in the enlarged group of specialties "Jurisprudence", with the qualification "lawyer", having the necessary professional and moral qualities, capable of performing the official duties assigned to them for health reasons (Article 40.1) [9]. The same thing is seen in the Law of the Russian Federation "On the status of judges in the Russian Federation": a judge can be a citizen of the Russian Federation who has a higher legal education in the specialty "Jurisprudence" or a higher education in the field of training "Jurisprudence" of the qualification (degree) "master" if he/she has a bachelor's degree in the field of training "Jurisprudence" (Article 4) [10]. These legislative specifications can be considered fair and justified.

It is also impossible not to say about the impact on legal education of one of the main trends of the present time - digitalization. Digitalization in education is the introduction of information technologies into the educational process for the transition to a personalized 
and result-oriented educational process [11]. Not everyone positively assesses this process, believing that this is nothing more than another "fashionable topic" that will pass, while the "eternal values" of education as the most stable public institution will remain the same. However, the authors believe that it is useless to deny the obvious things - digitalization has already become part of the education system, which is also confirmed by the state: the National Project "Education" notes that "accessibility of all types of education is impossible without creating a modern digital environment" [12]. Accordingly, the introduction of this process into education poses a number of tasks for it - not only material and technical support but also the development of new educational technologies, as well as a system for monitoring training and improving the digital literacy of all parties to this process. However, it is worth noting a trend among teachers - not everyone is ready to actively participate in this process, and in a number of areas, there is an outflow of teachers from educational institutions [13].

The driver of digitalization in education was 2020, when, under the conditions of coronavirus restrictions, education switched to a distance learning mode. However, it is important to understand here that the digitalization of the educational environment and the distance learning mode are not the same things: digitalization is a broader concept that includes some kind of automation of educational processes; the distance mode has become more of a part of digitalization and at many universities has been reduced to the possibility of conducting classes in video conferencing mode.

Some authors believe that the introduction of artificial intelligence as the main trend of digitalization will deprive lawyers of work [14]. Indeed, in a number of countries, one can observe such an experience: in China, artificial intelligence makes decisions when considering simple cases. However, the authors do not share this point of view and believe that the legal profession is very individualized and requires a thoughtful and professional approach.

\section{Discussion}

Without detracting from the positive features of both digitalization and the distance mode for legal education, one nevertheless should note a number of aspects of legal education, where it is important to maintain the mode of personal interaction between the teacher and law students:

a) an important direction of training a high-level specialist at the Faculty of Law is the expansion of cultural horizons, the formation of a personal worldview position, the development of students' legal awareness, a value-normative system with a predominance of socially significant values and priorities. In this regard, one can mention an interesting study that was conducted in 2013 by the Laboratory of Socio-Legal Research and Comparative Law "New educational standards in the assessments of students of the Faculty of Law of the Lomonosov Moscow State University". These studies have shown that for students of the Faculty of Law of Moscow State University, it is necessary to introduce such a lecture course as psychology into the curriculum [15]. A lawyer should be able to communicate with people, establish psychological contact, analyze motivation, etc. Mastering the skills of communicative competence, public speaking, self-presentation, knowledge and understanding of people cannot be taught online. For example, at Harvard Law School, there are courses and training based on experience, involving personal intensive participation [16].

b) the same can be said about teaching one of the basic disciplines - criminology: in accordance with the Federal State Educational Standard, the minimum list of material and 
technical support necessary for the implementation of the bachelor's program includes a specialized classroom equipped for conducting classes in criminology. The most obvious set of tools in this regard is the so-called "investigative briefcase": for future lawyers, classes on the use of fingerprinting techniques are of the greatest interest, which allows students to come into contact with practical activities, feel like specialists, experts.

Another serious problem of the distance learning mode has been the decline in the quality of education: not all teachers are ready to switch to a new learning mode that does not involve feedback from the student; students, for their part, are not always ready to take greater responsibility for learning outcomes, quick access to information generates a false sense of competence. In continuation of this thought, it is worth evaluating the value of the system of point-rating evaluation of students' work: on the one hand, this system has become a powerful stimulating factor - the student can see the results of his/her work in real time; on the other hand, students are guided not by obtaining new knowledge, but by obtaining an appropriate number of points, the achievement of the established limit of which contributes to the loss of interest in learning.

Thus, it can be stated that the scientific and technological progress that has taken place, as everywhere else - in all spheres of activity, makes it easier to work, leads to the need to rethink the ongoing processes and make the necessary decisions.

\section{Conclusion}

As a result of the conducted research, the authors conclude that legal education in modern conditions is changing, responding to the realities and challenges of the time: the training of high-quality lawyers should be based on a deep understanding of the specifics of this profession, which is reflected in the relevant educational standards and federal legislation. At the same time, it is impossible to deny the impact of digitalization on the educational process and the legal profession, which should be taken into account by universities and implemented in the process of preparing for the legal profession.

\section{References}

1. Federalnyi Zakon Ob obrazovanii v Rossiiskoi Federatsii [Federal Law" On Education in the Russian Federation"] Accessed on: October 4, 2021. [Online]. Available: http://pravo.gov.ru/proxy/ips/?docbody=\&nd=102162745

2. N.V. Babinova, Pedag Edu Rus, 4, 45-50 (2015)

3. V.S. Bezrukova, Osnovy dukhovnoi kultury (entsiklopedicheskii slovar pedagoga) [Fundamentals of spiritual culture (an encyclopedic dictionary of a teacher)]. (Ekaterinburg, 2000)

4. S. Eriksson, Obuchenie, orientirovannoe na uchenika. Na primere finskoi sistemy obrazovaniya [Student-centered learning. On the example of the Finnish education system]. Accessed on: October 4, 2021. [Online]. Available: https://education.forbes.ru/authors/obuchenie-orientirovannoe-na-uchenika

5. Konstitutsiya Rossiiskoi Federatsii [The Constitution of the Russian Federation]. Accessed on: October 4, 2021. [Online]. Available: http://www.kremlin.ru/acts/constitution

6. K.A. Strus, E.R. Arakelyan, Quest Mod Jurisp, 27, 136-139 (2013) 
7. Federalnyi gosudarstvennyi obrazovatelnyi standart vysshego obrazovaniya - stepen bakalavra po napravleniyu podgotovki 40.03.01 Yurisprudentsiya [Federal State educational standard of Higher Education-Bachelor's degree in the field of training 40.03.01 Jurisprudence"]. Accessed on: October 4, 2021. [Online]. Available: http://fgosvo.ru/uploadfiles/FGOS\%20VO\%203++/Bak/400301_B_3_07092020.pdf

8. Federalnyi gosudarstvennyi obrazovatelnyi standart vysshego obrazovaniya magistratura po napravleniyu podgotovki 40.04.01 Yurisprudentsiya [Federal State educational standard of higher education-Master's degree in the direction of training 40.04.01 Jurisprudence"]. Accessed on: October 4, 2021. [Online]. Available: http://fgosvo.ru/uploadfiles/FGOS\%20VO\%203++/Mag/400401_M_3_11032021.pdf

9. Federalnyi Zakon O prokurature Rossiiskoi Federatsii [Federal Law "On the Prosecutor's Office of the Russian Federation"]. Accessed on: October 4, 2021. [Online]. Available: http://pravo.gov.ru/proxy/ips/?docbody=\&nd=102014157

10. Zakon Rossiiskoi Federatsii O statuse sudei v Rossiiskoi Federatsii [The Law of the Russian Federation "On the status of judges in the Russian Federation"]. Accessed on: October 4, 2021. [Online]. Available: http://pravo.gov.ru/proxy/ips/?docbody=\&nd=102017065

11. Sem zadach tsifrovizatsii rossiiskogo obrazovaniya [Seven tasks of digitalization of Russian education]. Accessed on: October 4, 2021. [Online]. Available: https://trends.rbc.ru/trends/education/5d9ccba49a7947d5591e93ee

12. Opublikovan pasport natsionalnogo proekta "Obrazovanie" [The passport of the national project "Education" has been published]. Accessed on: October 4, 2021. [Online]. Available: http://government.ru/info/35566/

13. M. Shirrell, Amer J Edu, 127(3) (2021). https://doi.org/10.1086/713828

14. S. Egorkin, Ischeznovenie yuridicheskoi professii. Mysli posle prokhozhdeniya garvardskogo kursa po iskusstvennomu intellektu [The disappearance of the legal profession. Thoughts after taking a Harvard course in artificial intelligence]. Accessed on: October 4, 2021. [Online]. Available: https://zakon.ru/blog/2020/06/09/ischeznovenie_yuridicheskoj_professii_mysli_posle_ prohozhdeniya_garvardskogo_kursa_po_iskusstvennomu

15. A.V. Klochkova, A.A. Sharonova, Bul Moscow Univ. Ser. 11. Law, 1, 43-52 (2014)

16. D. Levina, Yuridicheskoe obrazovanie v SShA. Lichnyi opyt studentki iz Rossii [Legal education in the USA]. Accessed on: October 4, 2021. [Online]. Available: https://education.forbes.ru/authors/yuridicheskoe-obrazovanie-usa 